\title{
Biochemical study of glutathione reductase (GSH-Red) in Tissue Homogenate of Breast Tumors
}

\author{
Peri H.Saifullah* \\ Fatin F. Al-Kazzaz ** \\ Zayzafoon N. N. Al-Azaw**
}

\begin{abstract}
:
Date of acceptance $13 / 7 / 2008$

Breast tumor patients generally have more oxidative stress than normal females. This was clear from significant decrease $(\mathrm{P}<0.05)$ in tissue GSSG-Red activity. The study had found that free radicals in malignant breast tumors were higher than benign tumors, therefore the GSH- Red might be used as markers for prognosis of the disease.

Results of molecular characterization show optimum enzyme concentration substrate conc., optimum $\mathrm{pH}$, temperature \& time \& effect of some (chemotherapies in constant conectrations) for GSSG-Red activity.
\end{abstract}

\section{Key words: glutathione reductase, Breast tumors.}

\section{Introduction:}

The breast is a large compound racemose gland, consists of a few ducts, which are connected to the nipple and open to the surface. The main function of the breast is the production and expression of milk. Development of the breast requires the co-ordinate action of many hormones (1)

The breast tumors may be described, as either benign or malignant (cancerous). The national center of cancer in Iraq predicts that there is an increasing of incidence breast cancer in Iraqi women for years $(1975-2000)^{(1)}$.

The important risk factors are: female sex and age, age of menarche and menopause, family history \& genetic factors. ROSs are the main cause of breast cancer which encompasses all highly reactive oxygen containing molecules, including free radicals. Some of ROSs are defined as a free radicals, any atom or molecule having an unpaired electron in its outer orbit as $\left(\mathrm{O}_{2}^{--}, \mathrm{OH}^{*}, \mathrm{COO}^{*}, \mathrm{CO}^{*}\right)$. others, are not radicals but active metabolites of oxygen, ex $\left(\mathrm{H}_{2} \mathrm{O}_{2}, \mathrm{HOCl}\right)$. ROSs formation sources are mitochondical respiratory chain, phagocytes, redox reaction, radiation, cigarette, smoke environmental pollution. Main ROSs are: (super oxide radical $\mathrm{O}_{2}^{\circ-}$, Hydrogen peroxide $\mathrm{H}_{2} \mathrm{O}_{2}$, hydroxyl radical $\mathrm{OH}^{*}$, nitric oxide $\mathrm{NO}$, singlet oxygen $\mathbf{O}_{2}^{-}$). A first line body defense against oxidative stress produced by generation of free radical and reactive oxygen species ROSs are antioxidants which can defined as (any substance which delays or inhibits oxidative damage to a target molecule ${ }^{(1)}$.

Antioxidants are classified to enzymatic (GSH-Pex, GSSG-Red, SOD, CAT ...) non enzymatic (vit.C, vit.E, bilirubin $\mathrm{GSH})^{(2)}$.

GSSG- Red (EC 1.6.4.2) molecular mass for the native enzyme (110 KD) and for each subunit of the dimer $(55 \mathrm{KD})^{(2,3)}$. The homodimeric enzyme is a member of the family of flavoprotein disulfide oxidoreductase. Each subunit has four domains; beginning at the $\mathrm{N}$ - terminus: an FADbinding domain; an NADPH- binding

\footnotetext{
*Chemistry Dept. College Science for Women, Univ. Baghdad .

**Chemistry Dept. College Science, Univ. AL - Mustansiria .
} 
domain, a central domain and an interface domain $^{(4)}$. The active site of GSSG- Red is at the dimeric interface, also it carries a redox active disulfide
(Cys-58- Cys-63) in its active site which is reduced by electron transfer from NADPH via the flavin ${ }^{(5,6)}$.Figure (1)

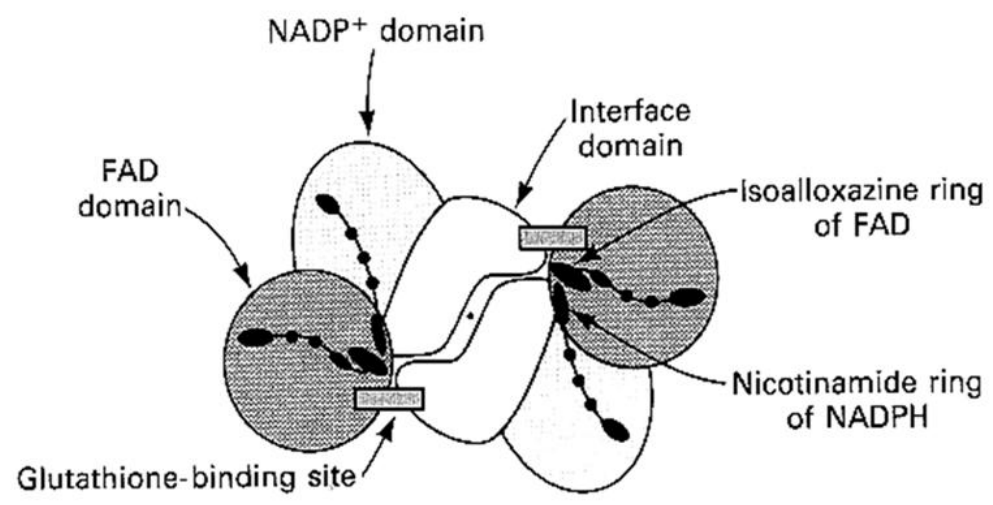

Figure (1:) The domain structure ring of NADPH of GSSG- Red

Since the GSSG binding site is composed of residues form both subunits, only the dimeric form is active $^{(7,8)}$
GSSG + NADPH + H $^{+} \stackrel{\text { GSSG-Red }}{\longrightarrow} 2$ GSH + NADP $^{+}$

Oixdized glulathion is reduced by amulti- steps reaction as shown below $^{(9,10)}$ :-

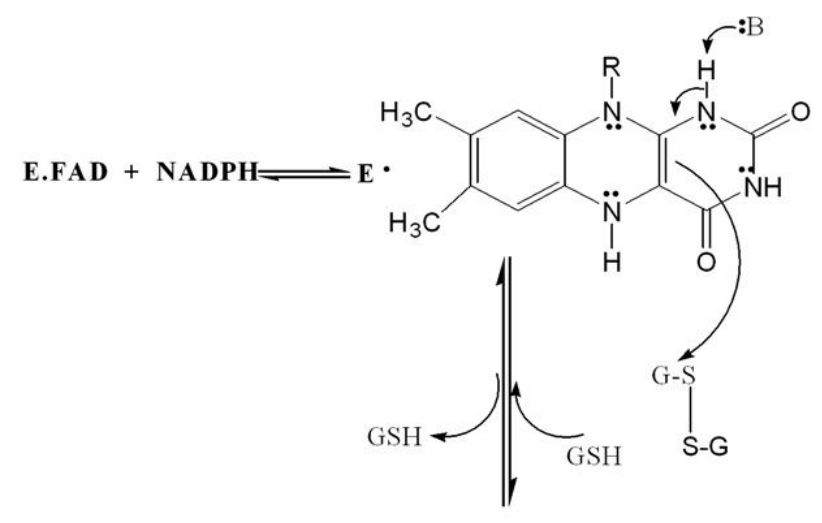

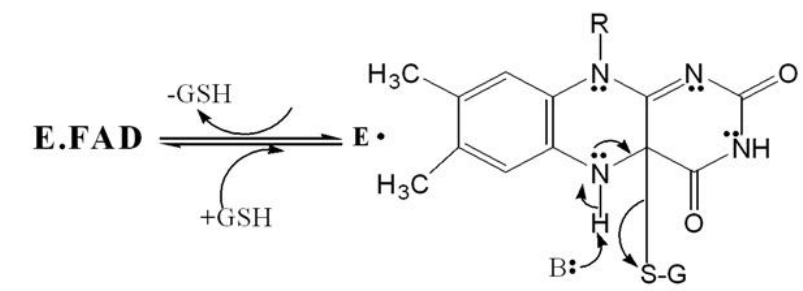


The main inhibitors of GSSG- Red (unknown mechanism): Oxidized glutathion $\mathrm{GSSG}^{(11)}, \mathrm{NADPH}^{(12)}, p$ hydroxy mercuribenzoic $\operatorname{acid}^{(13)}$. Another studies suggested some inhibitors of GSSG- Red and the mechanisms of inhibition as: Becker et al., found two ways to inhibit crystalline erythrocyte GSSG- Red

(a) As a reversible inhibitor: Inhibitor is competitive with glutathion disulfide (GSSG), the $\left(\mathrm{K}_{\mathrm{i}}\right)$ being approximately $0.5 \mathrm{mM}$

(b) As an irreversible inhibitor:

This inhibitor depends on the presence of NADPH and could not be reversed by dilution nor by reducing agents ${ }^{(14)}$. Whereas Petrickova et al., suggested that the inhibition effect of tested polyanions was caused by electrostatic interactions with enzyme, the kinetic analysis indicate that it is a mixed inhibition with respect to oxidized glutathione of $\mathrm{NADPH}^{(15)}$. Some inhibitors of this enzyme are: $\left(\mathrm{ZnCl}_{2}\right.$, nitrosative stress, inorganci; organic arsenic, dextran sulfate \& heparine) $(16,17,18,19,20)$

An investigation by Coban et al., for GSSG- Red activity in normal \& neoplastic human breast tissue found that the mean activities of GSSG- Red in tumour tissues were significantly higher than those in normal tissues ${ }^{(21)}$, as well as Seven et al., studied the oxidative stress \& GSSG- Red activity by measuring GSH redox cycle parameters in benign \& malignant breast disease ${ }^{(22)}$

\section{Materials \& Methods:}

Chemicals:

\begin{tabular}{|c|c|}
\hline Tris (hydroxyl methyl) methylamine & $\begin{array}{c}\text { BDH chemical Ltd, } \\
\text { England }\end{array}$ \\
\hline Disodium hydrogen phosphate & $\begin{array}{c}\text { BDH chemical Ltd, } \\
\text { England }\end{array}$ \\
\hline Ethylene diamin tetra acetic acid & $\begin{array}{c}\text { BDH chemical Ltd, } \\
\text { England }\end{array}$ \\
\hline Sodium carbonate & $\begin{array}{c}\text { BDH chemical Ltd, } \\
\text { England }\end{array}$ \\
\hline Sodium Potassium tartarate & $\begin{array}{c}\text { BDH chemical Ltd, } \\
\text { England }\end{array}$ \\
\hline Copper sulfate (hydrate) & Sigma chemicals, USA \\
\hline Sodium dihydrogen phosphate & Sigma chemicals, USA \\
\hline Disodium hydrogen phosphate & Sigma chemicals, USA \\
\hline $\begin{array}{c}\text { Nicotinamid adenine dinucleotid } \\
\text { phosphate (reduced) disodium salt }\end{array}$ & $\begin{array}{c}\text { Merck, chemicals } \\
\text { Germany }\end{array}$ \\
\hline Oxidized glutathione & Sigma chemicals, USA \\
\hline $\begin{array}{c}\text { Bovin serum albumine } \\
\text { Folin- Ciocalteau (phosphor } \\
\text { molybdo tungstic) }\end{array}$ & Sigma chemical, USA \\
\hline
\end{tabular}

\section{Patients:}

Four groups of breast tumor patients were included in this study:-

\begin{tabular}{|c|c|}
\hline Group I: & $\begin{array}{c}\text { Consisted of (33) pre-menopausal patients with } \\
\text { benign breast tumors }\end{array}$ \\
\hline $\begin{array}{c}\text { Group } \\
\text { II: }\end{array}$ & $\begin{array}{c}\text { Consisted of (19) pre-menopausal patients with } \\
\text { malignant breast tumors }\end{array}$ \\
\hline $\begin{array}{c}\text { Group } \\
\text { III: }\end{array}$ & $\begin{array}{c}\text { Consisted of (5) postmenopausal patients with } \\
\text { benign breast tumors }\end{array}$ \\
\hline $\begin{array}{c}\text { Group } \\
\text { IV: }\end{array}$ & $\begin{array}{c}\text { Consisted of (16) postmenopausal patients with } \\
\text { malignant breast tumors }\end{array}$ \\
\hline $\begin{array}{c}\text { Group } \\
\text { V: }\end{array}$ & Consisted of (34) healthy subjects \\
\hline
\end{tabular}

The patients were recently diagnosed and were not undergone any type of therapy. Patients suffered from other diseases that may interfere with our study were excluded. All patients were admitted for diagnosis \& surgery to (Al-Yarmok Teaching Hospital, Baghdad Teaching Hospital, Nursing Home Hospital). 
Table (1): The host information of breast tumor patients and healthy subjects studied

\begin{tabular}{|c|c|c|c|c|}
\hline Group & Patients & No. & Age & $\begin{array}{c}\text { Type of tumor } \\
\end{array}$ \\
\hline \multirow{4}{*}{ I } & \multirow{4}{*}{$\begin{array}{l}\text { pre-menopausal benign breast } \\
\text { tumors }\end{array}$} & \multirow{4}{*}{33} & \multirow{4}{*}{$16-49$} & - Fibrocystic changed adenosis \\
\hline & & & & - Axillary lymph nodes \\
\hline & & & & - Fibro adenoma \\
\hline & & & & - Duct papilloma \\
\hline \multirow{2}{*}{ II } & \multirow{2}{*}{$\begin{array}{l}\text { pre-menopausal malignant breast } \\
\text { tumors }\end{array}$} & \multirow{2}{*}{19} & \multirow{2}{*}{$16-49$} & - Infiltrattive ductal carcinoma \\
\hline & & & & - InSitu carcinoma \\
\hline \multirow{3}{*}{ III } & \multirow{3}{*}{$\begin{array}{c}\text { postmenopausal benign breast } \\
\text { tumors }\end{array}$} & \multirow{3}{*}{5} & \multirow{3}{*}{$50-65$} & - Duct Papilloma \\
\hline & & & & - Axillary Lymph nodes \\
\hline & & & & - Fibrocystic Changed \\
\hline IV & $\begin{array}{l}\text { postmenopausal malignant breast } \\
\text { tumors }\end{array}$ & & & $\begin{array}{l}\text { - Infiltrattive ductal carcinoma. } \\
- \text { Fat necrosis. } \\
\begin{array}{l}\text { Several patient's with metastasis \& recurrence breast } \\
\text { carcinoma after mastectomy \& radio or } \\
\text { chemotherapy. }\end{array} \\
\end{array}$ \\
\hline $\mathbf{v}$ & Control & 34 & $20-45$ & \\
\hline
\end{tabular}

Non of the patients were on a special diet, or taking any antioxidants (Vitamins E, Vitamins $\mathrm{C}, \ldots$ etc) or treated with antioxidant drugs except (Voltarin, Ampy Glucose, Paracetol), non of patients were exposured directly to radiation and didn't drink alcohol or smoke, negative genetic factor to have cancer with very clearly irregular menstrual cycle in most patients.

\section{Sample Collection:}

Tumor tissues were surgically removed from breast tumor patients by either mastectomy (cancer patients) or lumpectomy (benign tumor patients). The specimens were cut off and immediately rinsed with ice-cold normal saline $(0.9 \% \mathrm{NaCl}, \mathrm{pH} 7)$ solution, \& stored at $\left(-20^{\circ} \mathrm{C}\right)$ until homogenization.

The frozen tissue was thawed \& worked as follow:

1) The blood \& adipose tissue were removed with enough cold normal salin $(0.9 \% \mathrm{NaCl})$.

2) Tissue was weighted.

3) Sliced finely with scalped in Petri dish standing on ice bath. The slices were further minced with scissors then homogenized by using a manual homogenizer in buffer solution (* for malondialdehyde measurement: weighted tissue was homogenized in $(20 \mathrm{mM})$ phosphate buffer $\mathrm{pH} 7.4$. * for
Glutathione reductase measurement [50 $\mathrm{mM}$ tris (hydroxyl methyl) methyl amine - $(0.1 \mathrm{mM})$ EDTA) $] \mathrm{pH} 7.6$ was

used).

The buffer was added in a ratio (1:3) (weight: volume) gradually to tissue. The homogenate was filtered through (4) layers of $x$-ray gauze size $(90 \mathrm{~cm} \times$ $5 \mathrm{~mm})$, then centrifuged at $(3000$ r.p.m) at $\left(4^{\circ} \mathrm{C}\right)$ for $10 \mathrm{~min}$ (for $\mathrm{MDA}$ ) and at (10000 r.p.m) at $\left(4^{\circ} \mathrm{C}\right)$ for 10 min (for GSSG- Red).

4) An aliquot was removed (supernate of the sample for determining protein concentration).

5) Sample immediately was frozen at ($20^{\circ} \mathrm{C}$ ) until assay, the supernatant was used through the study ${ }^{(23,24)}$.

\section{Solutions:}

[Tris(hydroxy methyl) methylamin (50mM)- EDTA (0.1mM)] $\mathrm{pH}=7.6$, was prepared by dissolving (1.514 gm) of Tris in $(250 \mathrm{ml})$ distilled water (Reagent C) and dissolving (0.0084 $\mathrm{gm})$ of EDTA in 250 distilled water (Reagent D), then $(60 \mathrm{ml})$ of reagent D were mixed with $10 \mathrm{ml}$ of reagent $\mathrm{C}$ and adjusted $\mathrm{pH}$. Volume was completed to $100 \mathrm{ml}$ distilled water \& adjusted $\mathrm{pH}$ again. The total protein of breast tumor tissue homogenate was determined by Lowry et al. Method ${ }^{(25)}$ 
using bovine serum albumin (BSA) as the standard protein.

\section{Calculations:}

The standard curve was obtained by plotting the absorbance against the corresponding concentrations of standard protein and used to determine the unknown protein concentration of the sample (breast tumor homogenate) as shown in fig (2).

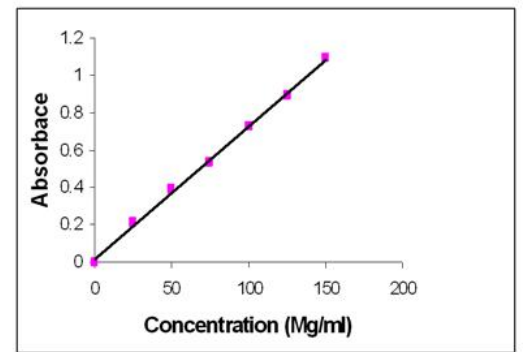

Figure (2) Standard curve of protein conc.

\section{Tissue glutathione reductase} (GSSG-Red) assay ${ }^{(26,27)}$ :

Reagents:

1) Reagent A: [Sodium phosphate buffer $(0.1 \mathrm{M}), \mathrm{pH}=7.4$ ]

2) Reagent B: $(0.025 \mathrm{~g})$ of NADPH was dissolved in $(10 \mathrm{ml})$ D.W. (freshly prepared).

3) Reagent C: $(0.11 \mathrm{~g})$ of (GSSG) was dissolved in $(10 \mathrm{ml})$ D.W. (freshly prepared).

4) Reagent D: (0.013g) of EDTA was dissolved in (10ml) D.W.

\section{Procedure:}

\section{Enzyme assay:}

\begin{tabular}{|c|c|c|}
\hline Reagents & Blank (ml) & Test $(\mathbf{m l})$ \\
\hline Reagent A & 2.6 & 2.6 \\
\hline Reagent D & 0.1 & 0.1 \\
\hline Reagent C & 0.1 & 0.1 \\
\hline Sample & - & 0.1 \\
\hline D.W & 0.1 & - \\
\hline Reagent B & 0.1 & 0.1 \\
\hline Final volume & 3.0 & 3.0 \\
\hline
\end{tabular}

The reaction was started by the addition of reagent $\mathrm{B}$ and absorbance was monitored (at $\lambda=340 \mathrm{~nm}$ ) and $\left(25^{\circ} \mathrm{C}\right)$ for $5 \mathrm{~min}$. time interval.

\section{Calculations:}

GSSG - Red activity intissue homogenate $U / \mathrm{g}$ protein

$=\frac{\frac{\Delta \mathrm{A}}{\mathrm{t}} * V_{T} * 1000}{\varepsilon * V_{S} * l *(\operatorname{Pr} \text { otein concentationg } / L)}$

$\Delta \mathrm{A}$ : Difference in absorbence

$\mathrm{V}_{\mathrm{T}}$ : Total volume of assay $=3.0 \mathrm{ml}$

$\mathrm{V}_{\mathrm{S}}$ : Sample volume $=0.1 \mathrm{ml}$

$\varepsilon$ : Extinction coefficient $=6.22 \mathrm{mM}^{-}$ ${ }^{1} \cdot \mathrm{cm}^{-1}$

1: length of light path $(1 \mathrm{~cm})$.

Determination of the optimum enzyme concentration $[E]$ in (tissue homogenate) for (GSSG-Red) reaction:

Procedure (1):

1) To a set of test tubes containing $(1.2 \mathrm{ml})$ of reagent $\mathrm{A},(0.05 \mathrm{ml})$ of reagent $\mathrm{D}$ was added and mixed.

2) To above mixture tubes, $(0.05 \mathrm{ml})$ of reagent $\mathrm{C}$ were added.

3) Different volume of tissue homogenate (supernatant) $\quad(0.0065$, $0.0125,0.025,0.05,0.1,0.125,0.15)$ $\mathrm{ml}$ were added individually to all set tubes. Mixtures volumes were completed by reagent $\mathrm{A}$ to $(1.45 \mathrm{ml})$.

4) The enzymatic reactions started by the addition $(0.05 \mathrm{ml})$ of reagent $B$. Absorbance was monitored (at $\lambda=$ $340 \mathrm{~nm})$ and $\left(25^{\circ} \mathrm{C}\right)$ for $5 \mathrm{~min}$. time interval.

Blank was contained all reagent except tissue sample.

Determination of the optimum substrate concentration [S] (GSSG) for the (GSSG-Red) reaction:

Procedure (2):

1) To a set of test tubes containing $(0.3 \mathrm{ml})$ of reagent $\mathrm{A},(0.05 \mathrm{ml})$ of reagent $\mathrm{D}$ was added and mixed. 
2) Different volume of reagent $\mathrm{C}$ (substrate) $(0.0125,0.025,0.05,0.1$, $0.125,0.15) \mathrm{ml}$ was added individually to all set tubes. Mixtures volumes were completed by addition reagent to $(1.425 \mathrm{ml})$.

3) Supernatant of tissue homogenate $(0.025 \mathrm{ml})$ was added to above mixture tubes.

4) The procedure was followed as step (4) in procedure (1).

Determination of the optimum $\mathrm{pH}$ for (GSSG-Red) reaction:

Procedure (3):

1) To a set of test tubes containing $(1.35 \mathrm{ml})$ of buffer in different acid function $\mathrm{pH}(5.4,6.4,7.4,8.4,8.9)$ were mixed with $(0.05 \mathrm{ml})$ of reagent D.

2) Reagent $\mathrm{C}:(0.025) \mathrm{ml}$ was added then to above mixture tubes

3 ) The procedure was followed as steps $(3,4)$ in procedure $(2)$

Determination of the optimum temperature (T) for (GSSG-Red) reaction:

\section{Procedure (4):}

1) To a set of test tubes containing $(1.325 \mathrm{ml})$ of (reagent $\mathrm{A}, \mathrm{pH} 7.4$ ), $(0.05 \mathrm{ml})$ of reagent $\mathrm{D}$ was added \& mixed.

2) The procedure was followed as steps $(2,3,4)$ in procedure $(3)$.

Absorbance was monitored (at $\lambda=$ $340 \mathrm{~nm})$ and different incubation temperature $\left(4,10,20,37,45^{\circ} \mathrm{C}\right)$ were used for $5 \mathrm{~min}$. time interval.

Determination of incubation time of (GSSG-Red) reaction:

\section{Procedure (5):}

1) The procedure was followed as steps $(1,2,3,4)$ in procedure (4).

Absorbance was monitored (at $\lambda=$ $340 \mathrm{~nm})$ and $\left(37^{\circ} \mathrm{C}\right)$ and different incubation time $(5,10,15,20,25,35,4$ 5) minutes.
Determination of the effect of some chemotherapy drugs used in Iraqi hospitals on (GSSG-Red) activity:

\section{Reagents:}

All reagents (A,B,C,D ) were described in (2.9.1)

Chemotherapy preparation:

- Methotrexate was added directly from its container in concentration $(0.0055 \mathrm{M})$. to enzymitic reaction of GSSG-Red without dilution.

- Doxorabicine was diluted from its original concentration $\left(3.4 \times 10^{-3} \mathrm{M}\right)$ to concentration $\left(1.7 \times 10^{-4} \mathrm{M}\right)$ by mixing $(0.5 \mathrm{ml})$ of Doxorubicine) with $(9.5 \mathrm{ml})$ of D.W.

Procedure (6):

1) To a set of test tubes containing $(1.325 \mathrm{ml})$ of (reagent $\mathrm{A}, \mathrm{pH}=7.4)$, $(0.05 \mathrm{ml})$ of reagent $D$ was added \& mixed.

Then $(0.05) \mathrm{ml}$ of Reagent $\mathrm{C}$ was added to above mixture.

2) To above mixture tubes, $(0.05) \mathrm{ml}$ reagent $\mathrm{C}$ was added.

3) Supernatant of tissue homogenate $(0.025 \mathrm{ml})$ and $(0.025 \mathrm{ml})$ of chemotherapy (methotrexate) was added to all set tubes $\&$ mixed.

4) The procedure was followed as step (4) in procedure (1).

The experiment was repeated again to test effect of chemotherapy (Doxorubicine) on GSSG-Red activity. Calculations:

In all above experiments results were expressed as $\mathrm{U} / \mathrm{g}$ protein conc.

GSSG-Redactivityin tissue//g proteinconc

$$
=\frac{\frac{\Delta \mathrm{A}}{\mathrm{t}} * V_{T} * 1000}{\varepsilon * V_{S} * l *(\text { Proteinconcg } / L)}
$$

\section{Discussion:}

Red blood cells (Rbcs) protect their cellular integrity and biovitel molecules such as proteins, enzyme \& membrane lipids from the injurious $\mathrm{O}_{2}^{-}$ 
effects by ROS, primarily $\mathrm{H}_{2} \mathrm{O}_{2}$ \& by conserving a constant high ratio of $\mathrm{GSH} / \mathrm{GSSG}^{(28)}$. The enzymatic activity responsible for maintain high intracellular GSH to GSSG is achieved by glutathione reductase. The enzyme GSSG-Red can catalyze the conversion of oxidized glutathione GSSG to the corresponding reduced form GSH \& the reaction proceeds by the presence of NADPH which is converted to $\mathrm{NADP}^{+}$.

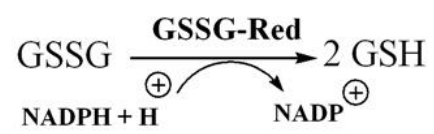

The enzyme activity can be monitoring by measuring the decrease in the absorbance at $340 \mathrm{~nm}^{(26,27)}$.

Tissue enzyme activity was significantly decreased $(\mathrm{P}<0.05)$ in patients with malignant tumor compared to benign for both pre \& post M.P. table (2).

Table (2): Tissue GSSG- Red activities $(\mathrm{U} / \mathrm{g}$ protein) in patients with breast tumor (pre \& post M.P.)

\begin{tabular}{|c|c|c|c|c|}
\hline \multirow{2}{*}{ Groups } & \multicolumn{2}{|c|}{ Malignant } & \multicolumn{2}{c|}{ Benign } \\
\cline { 2 - 5 } & Post MP & Pre MP & Post MP & Pre MP \\
\hline $\begin{array}{c}\text { No. of } \\
\text { samples }\end{array}$ & 10 & 9 & 2 & 9 \\
\hline Mean & 155.83180 & 110.2741 & 222.6065 & 275.14744 \\
\hline \pm SD & 47.366413 & 30.9477 & 26.23469 & 160.71334 \\
\hline T- test & -4.458 & -15.982 & & \\
\hline Probability & 0.002 & 0 & & \\
\hline
\end{tabular}

Also the activity in benign tumors for pre M.P was more than in post M.P, but in malignant disease, post M.P patients had enzyme activity more than pre M.P

Post study in normal human breast conclude that the redox balance in cultured normal human breast epithelial cells was altered by change condition lead to the increased death of cells subsequently exposed to $\mathrm{H}_{2} \mathrm{O}_{2}$, and this caused decrease in GSSG- Red activity as our results shown ${ }^{(29)}$.

The results may indicate a possible relation between the decreasing in activities of GSSG- Red enzyme \& increasing levels of DNA base lesions due to oxidative damage, and support the notion that free radicals reactions may be increased in malignant cells ${ }^{(30)}$. Some factors may also play essential roles in defect of GSSG- Red activity. First: the depletion in riboflavin (vitamin $\mathrm{B}_{2}$ ) the supplemental of FAD, which acts as prosthetic group, FAD is important in full- function catalytic activity ${ }^{(6,31,32)}$. The second factor is: the error in hexose- monophophate pathway which supplies adequate amount of reducing equivalent as NADPH to be used as electron acceptor in the reaction catalyzed by GSSG- Red ${ }^{(33)}$

The noticed decrease of enzyme activity in tissue of breast tumors patients (especially malignancy) may refer to increase permeability of tissues membranes due to oxidation of lipid membranes (increase MDA) by ROS $\&$ decrease (GSH) the first line of defense.

In the presence of reduced nicotinamide adenine dinucleotide phosphate (NADPH), the flavin enzyme glutathione reductase (GSSGRed) catalyses the reduction of oxidized glutathione (GSSG) to reduced glutathione $(\mathrm{GSH})^{(27)}$

$\mathrm{GSSG}+\mathrm{NADPH}+\mathrm{H}^{+} \stackrel{\text { GSSG-Red }}{=} 2 \mathrm{GSH}+\mathrm{NADP}^{+}$

Michalis- Menton proposed that enzyme - catalyzed reaction proceed in two steps as the kinetic scheme is

$$
\text { show: } \frac{K_{1}}{K_{-1}} \mathrm{ES} \stackrel{K_{2}}{\longrightarrow} \mathrm{E}+\mathrm{P}
$$

This proposed model, is the simplest one that accounts for the kinetic properties of many enzymes $\left(\mathrm{K}_{\mathrm{m}}\right.$ \& $\left.\mathrm{V}_{\max }\right)^{(4,34)}$. 
We studied the optimum conditions to binding the substrate GSSG and the enzyme GSSG- Red which present in breast tumors homogenate as below:

Different amount of breast tumors homogenate were used to determine the optimum [E] concentration.

The optimum [E] for pre M.P patients were (malignant tumors $=12 \times 10^{-7}$ $\mathrm{g} / \mathrm{ml}$, benign tumors $=11 \times 10^{-7} \mathrm{~g} / \mathrm{ml}$ ), and for post M. P patients were (malignant tumors $=4 \times 10^{-7} \mathrm{~g} / \mathrm{ml}$, benign tumors $=6 \times 10^{-7} \mathrm{~g} / \mathrm{ml}$ ).

This result means that GSSG- Red in post M.P. patients is saturate by substrate (GSSG) in enzyme concentration less than that in pre M.P due to the high concentration of enzyme in pre M.P compared to those in post M.P \& this was clear from the catalytic activity of GSSG- Red in pre M.P more than in post M.P.

We found that optimum (GSSG) concentration for post \& pre M. P patients in two types of tumors malignant \& benign was $\left(5.59 \times 10^{-4} \mathrm{M}\right.$ $\approx 2.6 \times 10^{-4} \mathrm{~g} / \mathrm{ml}$ ).

The rate of reaction is directly proportional to the concentration of substrate (GSSG) only for very low initial [GSSG]. The reaction thus approaches first order in this region of curve. At high initial [GSSG], the enzyme is saturated with GSSG and the rate of reaction is independent on [GSSG].

The decreasing in GSSG-Red activity after this region may refer to inhibition of enzyme by substrate (GSSG). This observation detected also by Robin. (35), who result that exogenase GSSG had a slight inhibitory effect because the enzymatic reaction requires only catalytic amounts of $\operatorname{GSSG}^{(36,37)}$

From hyperbolic curve $\mathrm{K}_{\mathrm{M}}$ (MichaelisMenten constant $)=\left(2 \times 10^{-4} \mathrm{M} \approx\right.$ $9.8 \times 10^{-5} \mathrm{~g} / \mathrm{ml}$ ) for all groups. That is mean that substrate (GSSG) has the same affinity for all four groups toward GSSG- Red.
Meeseet ${ }^{(27)}$,, found that maximum GSSG- Red activity was obtained for $\left([\mathrm{GSSG}]=\left(3.6 \times 10^{-4}\right.\right.$ to $\left.9.1 \times 10^{-5} \mathrm{~g} / \mathrm{ml}\right)$ in Rbcs \& plasma of healthy donors ${ }^{(27)}$. The $K_{m}$ values for majority of enzymes are of the order of $\left(10^{-5}\right.$ to $\left.10^{-3} \mathrm{M}\right)$; therefore, substrate concentrations are usually chosen to be in the range of $\left(10^{-}\right.$ ${ }^{3}$ to $10^{-1} \mathrm{M}$ ).

On occasion, the optimal concentration of substrate cannot be used, for example, when the substrate had limited solubility or when the concentration of a given substrate inhibits the activity of another enzyme needed in a coupled reaction system (38)

A change in $\mathrm{pH}$ can alter the rates of enzyme catalyzed reaction with many enzyme exhibiting a bell shaped curve when enzyme activity is plotted against $\mathrm{pH}$. The optimum $\mathrm{pH}$ for each four groups was 7.4, and notice decrease enzyme GSSG-Red activity after or before this $\mathrm{pH}$.

Explanation of enzyme behavior at this $\mathrm{pH}$, due to that many enzyme show maximum activity in vitro in $\mathrm{pH}$ range from $(7-8)^{(38)}$

Acidic function pH 7.4 make (GSSG) substrate or coenzyme (NADPH) and enzyme in good ionization state that shall be optimally bound together to give product ${ }^{(39)}$, certain key amino acid (cystine) side chains in protein molecule effected by both $\mathrm{pH} \&$ ionic environment \& this have an effect on the three dimensional conformation of the protein and therefore on enzyme activity. At extreme values of $\mathrm{pH}$ enzyme may be irreversibly denatured $(39,40)$. This finding was in agreements with Meeseet ${ }^{(27)}$.., study, that suggest that the optimum $\mathrm{pH}$ is (7.4) for GSSG- Red in RBCs \& plasma of healthy donors ${ }^{(27)}$.

All biochemical reactions are effected by temperature. In general, the high temperature is getting increase a reaction's rate. The optimum 
temperature for each four group were $37^{\circ} \mathrm{C}^{(40)}$,

Before this temperature GSSG-Red activity is too low because it can't provide enough kinetic energy to overcome the energy of activation (energy barrier) $^{(40)}$, then the increase in reaction velocity is due to an increase in the number of molecules that have sufficient energy to enter into the transition state, followed by a decrease in GSSG-Red activity as the temperature continues upward with increasing break down of linkage between GSSG-Red enzyme \& substrate (GSSG) include electrostatic attraction, hydrogen bonding, Vander Waals forces and hydrophobic interaction, rise in temperature leads also to thermal denaturation of protein aqueous enzyme molecule ${ }^{(41,42)}$

Workers still use $37^{\circ} \mathrm{C}$ for most determinations, which was chosen for early enzyme assays because it is the body or "physiological" temperature ${ }^{(43)}$.

The activity of GSSG-Red increase by increasing the incubation time allowing to the enzyme to be completely saturated with the substrate GSSG until it reach to optimum time course, then incubation of binding mixture for time periods longer than that required for maximum binding resulted in decrease binding; this may be due to reversible dissociation of the complex after reaching to the equilibrium state ${ }^{(44)}$.

Meesseet ${ }^{27)}$., found that maximum time course in RBCs \& plasma of healthy donors for GSSG- Red was 30 $\min ^{(27)}$.

(Methotrexat) \& (Doxorubicin) work as activators of GSSG-Red activity in tissues homogenate for each four groups of patients.
We found also that Methotrexat behave as an activator more than Doxorubicin for GSSG-Red activity in each four groups of patients.

This effect of chemotherapies drugs may be due to the fact that Metho.\& Doxo. reduce the active sites (Cys 63Cys 58) on enzyme. Thus, making it again reactive in vitro conditions, this contribute to the structure of Metho. which have two carboxylic groups (acidic), which can donate two electron to oxidized enzyme \& reduced it to $\left(\mathrm{EH}_{2}\right)$ the active form, this state can be seen it in Doxo which have anthracycline ring can undergo a one electron reduction $^{(45,46)}$.

\section{References:}

1. JEC Underwood. 2000. General \& systematic pathology $\left(3^{\text {rd }}\right.$ ed.). Harcourt Publishers limit china. $\mathrm{pp}=760$.

2. Molecular forms \& thermal kinetic properties of purified GSSGRed.2000.

3. Southern P. A 1988. Free radical in medicine. I. Chemical nature \& biologic reactions. Mayo. Clin. Proc. p63: 381-389.

4. L. Strye .1988, r: Biochemistry. $\left(3^{\text {rd }}\right.$ ed.). W. H. Freeman Company/ New York. pp: 398, 436-438.

5. Williams C. H. Jr. 1992. Chemistry \& Biochemistry of flavoenzymes (Müller, F., ed.), CRC Press, Boca Raton, FLvol.3, pp: 375.

6. Beutler E. , 1969. Glutathione reductase: Stimulation in normal subjects by riboflavin supplementation. Science; 165: 613.

7. Dolphin D., Poulson R., Avramovic O 1989. Glutathione: Chemical, Biochemical and Meatabobolic. Aspects, Vols. A and B, J. Wiley and Sons.

8. Bashir A., Perham R. N., Scrutton N. S., Berry A 1995. Altering 
Kinetic Mechanism and enzyme stability by mutagenesis of dimer interface of glutathione reductase. Biochem. J. 312: 527-533.

9. Massey V., Williams C. H. 1965. on the mechanism of yeast glutathione reductase. J. Biol. Chem. 240(11) 4470-4480.

10. G. Zubay, 1993. Biochemistry $\left(3^{\text {rd }}\right.$ ed.)WMC. Brown communications. Inc./USA. vol.2, $\mathrm{pp}=253$

11. Bairoch A. Boeckman B., 1990. The Swissprot protein sequence data bank, recent developments. Nucleic Acids Res. 21: 3093-3096.

12. Decnarain M. P., Scrutton N. S., Berry A., Perham R. N. 1990. Directed Mutagenesis of the redoxactive disulphide bridge in glutathione reductase from Escherichia Coli. Proc. Rsoc. Lond B. Biol. Sci. 241(1302): 179-186.

13. Mata A. M., Pinto M. C., LopexBarea J. 1990 Purification by affinity chromotography of glutathione reductase (Ec 1.6.4.2) from Escherichia coli \& characterization of such enzyme. Z Naturforsch [C] Nil, 39(9-10): 908-915.

14. Becker K. M., Schirmer R. H. 1995. Inhibition of human GSSG-Red by S-nitroso glutathione. Eur-JBiochem. 234(2):472-478.

15. Paulikova H., Petrickova I., Antalik M., Podhradsky D. 1996. Effect of heparin and dextran sulfate on the activity of GSSG- Red from yeast. Biochem- Mol-Biol-Int. 38(6): 1117-1126.

16. Schuliga, -M, Chouchane, -S, Snow, -E, T, 2002. upregulation of glutathione- related genes \& enzyme activities in cultured human cells by sublethal concentrations of inorganic arsenic. Toxicol- Sci. 70(2): 183, 192.

17. Wilhelim B, Walther U.I., Fichtl B 2001. Effects of zinc chloride on glutathione \& glutathione synthesis rates in various lung cell lines. Arch- Toxicol. 75(7): 388-394.

18. Paulikova H., Petrickova I., Antalik M., Podhradsky D, 1996. Effect of heparin \& dextran sulfate on the activity of glutathione reductase from yeast. BiochemMol- Biol. Int. 38(6): 1117-1126.

19. Fujii T., Hamaoka R., Fujii J., Taniguchi N. 2000. Redox capacity of cells effects in activation of GSSG- Red by nitrosative stress. Arch- Biochem- Biophys 1. 378(1): 123-130.

20. Chouchane S., Snow E. T. 2001. In vitro effect of arsenical compounds on glutathione -related enzymes. Chem- Res- Toxicol. 14(5): 517-522

21. Iscan M., Coban T., Bulbul D., Eke B. C., Aygomez Z., Berberoglu U. 1998. Xenobiotic metabolizing \& antioxidant enzymes in normal and neoplastic human breast tissue. Eur-J-Drug-MetabPharmacokinet. 23(4): 497-500.

22. Seven A., Erbil Y., Seven R., Inci F., Gulgasar T., barutcu B., Candan G., 1998. Breast cancer \& benign breast disease. Cancer- BiochemBiophys. 16(4): 333-345.

23. Botsoglou, N. A. 1994. Rapid, Sensitive, and Specific thiobarbituric acid method for measuring lipid peroxidation in animal tissue, food \& feedstuff samples. J. Agric. Food Chem. 42: 1931-1937.

24. Carlberg, I. And mannervik B.: Glutathione reductase. Methods Enzymol. 1995. 113: 484-490.

25. Lowry O., Rosebergh N., Farr L., \& Ronall J. 1951. J. Biol. Chem. 193: 265.

26. Dabrosin C., hammar M., Ollinger K 1998. Impact of oestradiol \& progesterone on antioxidant activity in normal human breast epithelial cells in culture. Free- Radic- Red. 38(3): 241-249. 
27. Lee. K., I. Koon T., A. Mee S 1975. A new colorimetric method for the determination of NADH/NADPH dependent GSSGRed in erythrocyte \& in plasma. Clinica. Chimica. Acta. 58: 101108.

28. Kidd P. M. 1999. GSH systemic protectant against oxidative \& free radical damage. Alt. Med. Rev. 2: 155-176

29. Dabrosin C., hammar M., Ollinger K. 1998. Impact of oestradiol \& progesterone on antioxidant activity in normal human breast epithelial cells in culture. Free- Radic- Red. 38(3): 241-249.

30. Senturker S., Karahalil B., Inal M., Yilmaz H., Muslumanoglu $H$., Gedikoglu G., Dizdaroglu M. 1997. Oxidative DNA base damage \& antioxidant enzyme levels in childhood acute lymphoblast Leukemia. FEBS- Lett. 27, 416(3): 286-290.

31. Beutler E. 1969. Effect of flavin compounds on glutathione reductase activity: In vivo and vitro studies. J. Clin.- Invest. b; 48: 1957.

32. Matthews F. S. . 1991. New Flavoenzymes. Curr. Dpin. Struct. Biol1: 954, 967.

33. Burton G. W., Joyce A., and Ingold K. U. 1983. Vitamin E the only lipid - soluble, chain- breakin antioxidant in human blood plasma and erythrocyte membrane, Arch. Biochem. Biophys, b; 221: 281290.

34. Frank B. Armstron 1989 Biochemistry. ( ${ }^{\text {rd }}$ ed.). Oxford University Press/ New York. chap: 8; pp: 126-128.

35. Robin J. Mockett, RA Jinar S. S.\& William C. $\quad$ O. 1999. Overexpression of GSSG-Red extends survival in transgenic
Drosophila mehnogaster under hypoxia but not normoxia, The FASEB J. 13: 1733-1742.

36. Tietze F. 1969. Enzymic method for quantitative determination of nanogram amounts of total \& oxidized glutathione. Anal. Biochem. 27: 502-522

37. Akerboom T. P. M., Sies H. 1981 Assay of glutathione, glutathione disulfide, and glutathione mixed disulfides in biological samples. Methods Enzymol. 77: 373-382.

38. Cal. A. Burtis, Edward R. Ashwood 1999. Clinical Biochemistry $\left(3^{\text {rd }}\right.$ ed.). W. B. Saunders company/ USA. vol.2; chap.; pp: 617-642.

39. Simic M. G. 1988. Mutation Res. 202: 377-386

40. Tomas M. Devlin,. 1986. Text book of biochemistry with clinical correlation. ( $2^{\text {nd }}$ ed.). A wiley Medical Puplication / SINGAPORE. chap. ; pp: 117-173.

41. James R. Mekee, Trudy M. 1996 Biochemistry/ An Introduction. (Developmental ed.). WM. C. Brown Publishers/ USA ; $\mathrm{pp}=894$.

42. Ian D. K. Halkerstone 1988. Biochemistry $\left(2^{\text {nd }}\right.$ ed. $)$. Harwall publishing company, Media, Pennsylvania, chap. 11; $\mathrm{pp}=435$.

43. Harold V., Alan H., Gowen lock, Maarice B. 1976. Practical clinical biochemistry $5^{\text {th }}$ ed., William Heinemann. Medical books limited, vol.1: 950.

44. Al-Mudhaffar S. A. 1983. Enzyme Kinetics. $\left(1^{\text {st }}\right.$ ed. $)$ Baghdad University. Part:2, pp: 49-126.

45. McCord M., Fridowich I. 1986. J. Biol. 244: 6049-6059.

46. Rawn J. D. 1989 Biochemistry. (International ed.). Neil Patterson publishers/ North Carolina. pp: 168-176. 


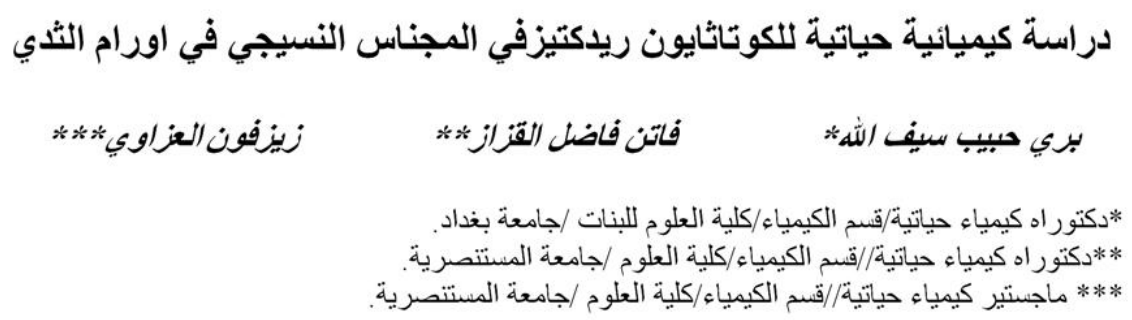

*دكتور اه كيمياء حياتية/قسم الكيمياء/كلية العلوم لللبنات /جامعة بغداد.

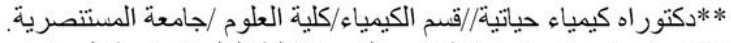
**** ماجستير كيمياء حياتية/قسم الكيمياء/كلية العلوم /جامعة المستنصرية.

النساء المصابات بسرطان الثدي يكونون بشكل عام اكثر عرضة للإجهاد التأكسدي مقارنة بالنساء غير

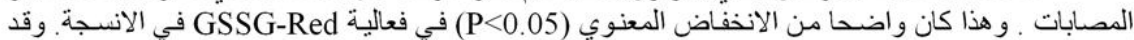

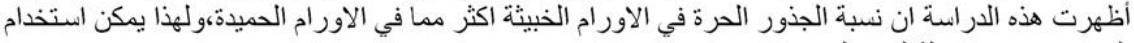

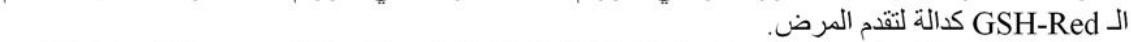

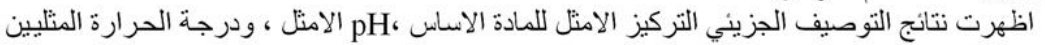

الخلاصة.

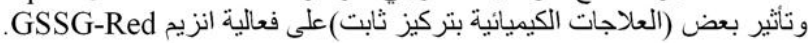

